\title{
Investigating the toxicity of tropical reservoir sediments using the Allium test
}

\author{
Quadra, G.R. ${ }^{*}$; CAmpos, J.M.S. ${ }^{2}$; Lino, A. ${ }^{3}$; Malm, O.. ${ }^{3}$ Guida, Y.3; Barros, N. ${ }^{3}$; Thomaz, J.R. ${ }^{3}$; \\ Silva, R. ${ }^{2} \&$ Roland, F. ${ }^{1}$ \\ ${ }^{1}$ Laboratório de Ecologia Aquática, Programa de Pós-Graduação em Biodiversidade e Conservação da Natureza, \\ Universidade Federal de Juiz de Fora, 36036-900, Brazil. \\ ${ }^{2}$ Laboratório de Genética e Biotecnologia, Universidade Federal de Juiz de Fora, 36036-900, Brazil. \\ ${ }^{3}$ Laboratório de Radioisótopos Eduardo Penna Franca, Instituto de Biofísica Carlos Chagas Filho, Universidade Federal \\ do Rio de Janeiro, 21941-901, Brazil.
}

Received July 06, 2020; Accept October 14, 2021

\begin{abstract}
Water pollution is a global environmental issue, and aquatic sediments are important compartments that might act as sinks or sources of contaminants. Once in the environment, inorganic contaminants such as metals can cause cytogenotoxic effects that damage genetic material and harm the aquatic community. Biological assays such as the Allium test can be used to investigate potential cytogenotoxicity of contaminated sediments based on the alterations of cell cycle indexes and chromosomal aberration frequencies. Therefore, we aimed to assess the toxicity of sediments from four Brazilian reservoirs using the Allium test. Sediments were sampled and elutriates were prepared in a simulating sediment resuspension in the water column. The Allium test was applied to the elutriates, and the metals copper, chromium, cadmium, lead, zinc, and iron were quantified. The elutriates derived from reservoir sediments were able to reduce the mitotic and anaphase index, increase the prophase and metaphase index, and boost chromosomal aberrations compared to the negative control. The cytogenotoxic effects observed may be linked to the presence of copper, zinc, and iron. Therefore, our results showed that the Allium test was a sensitive tool for warning the occurrence of genotoxic contaminants in sediment elutriates from four Brazilian reservoirs.
\end{abstract}

Keywords: aquatic ecosystems; cytogenotoxicity; chemicals; contaminants; genotoxic; elutriate; metals; water quality.

\section{INTRODUCTION}

Anthropogenic activities discharge a pool of contaminants into freshwater ecosystems, and water pollution has become a severe environmental issue worldwide (Schwarzenbach et al., 2010; Quadra et al., 2019a). The mixture of contaminants received by aquatic ecosystems can cause mutagenic effects and harm ecological functions (Lee et al., 2003; Lemos et al., 2009). Adverse effects on human health may also occur due to lifelong exposure to contaminants by drinking water and food consumption (Buschini et al., 2008; Castro-González et al., 2008).
Freshwater reservoirs are created for energy production, irrigation, and water storage (Suen et al., 2006; Tundisi, 2018). Reservoirs can present high sedimentation rates (Mendonça et al., 2017) and become important contaminant sinks (Zoumis et al., 2001; Massoudieh et al., 2010). However, once in the sediment, the contaminants may return to the water column via resuspension processes, causing toxicity to aquatic organisms (Zoumis et al., 2001; Eggleton et al., 2004; Cardoso et al., 2019).

Biological tests can be used to assess the toxicity of individual chemicals or a complex mixture of contaminants present in the environment in an integrated way, such as 
sediments, providing support for safer decisions (Heise et al., 2020). Previous studies have already used the Allium test to assess cytogenotoxicity caused by contaminants in aquatic ecosystems since it is a highly sensitive tool and presents an excellent correlation with other groups of organisms (Rambo et al., 2017; Freitas et al., 2017; Dieterich \& Gaete, 2021). For that reason, we aimed to investigate the cytogenotoxicity of sediment elutriates from four freshwater reservoirs in the Brazilian Southeast using the Allium test. Copper $(\mathrm{Cu})$, chromium $(\mathrm{Cr})$, cadmium $(\mathrm{Cd})$, lead $(\mathrm{Pb})$, zinc $(\mathrm{Zn})$, and iron $(\mathrm{Fe})$ were quantified in the sediment elutriates to infer potential causes of detected toxicity.

\section{MATERIAL AND METHODS}

\section{Study areas}

The sediment samples were collected in four reservoirs located in the Brazilian Southeast: Furnas (FNS, S $\left.21^{\circ} 13^{\prime} 54.84^{\prime \prime} \mathrm{W} 45^{\circ} 57^{\prime} 19.02^{\prime \prime}\right)$ and Chapéu D’Uvas (CDU, S $21^{\circ} 35^{\prime} 15.52^{\prime \prime}$ W $\left.43^{\circ} 33^{\prime} 10.68^{\prime \prime}\right)$ in Minas Gerais state, Santa Fé (SNF, S $22^{\circ} 3^{\prime} 58.46^{\prime \prime} \mathrm{W} 43^{\circ} 9^{\prime} 54.40^{\prime \prime}$ ) and Funil (FUN, S $22^{\circ} 31^{\prime} 10.89^{\prime \prime} \mathrm{W} 44^{\circ} 37^{\prime} 30.04^{\prime \prime}$ ) in Rio de Janeiro state (Figure 1). In 1963, FNS was created with a flooded area of $1327 \mathrm{~km}^{2}$, and it is mainly used for electricity generation and irrigation (Ometto et al., 2013). In 1995, CDU was created primarily for water supply, with an area of $12 \mathrm{~km}^{2}$ (Quadra et al., 2019b). In 2008, SNF was created for electricity generation, with an area of $2.05 \mathrm{~km}^{2}$. In 1969, FUN was created with a flooded area of $26 \mathrm{~km}^{2}$, and it is mainly used for aquaculture, water, and energy supply (Soares et al., 2008; Ometto et al., 2013).

\section{Sampling and samples treatment}

Sediment samples were collected in the dry season near the dam using a gravity corer (Mudroch et al., 1994; Chapman, 1996). After sampling, the treatment was adapted from Dieterich \& Gaete (2021), trying to stimulate a lighter resuspension, according to Magdaleno et al., (2008) and Messias (2008). Briefly, after sampling, the sediment samples were dried at $40{ }^{\circ} \mathrm{C}$ to remove humidity until constant weight. The surface layer of sediment $(20 \mathrm{~cm})$ was then used to prepare sediment elutriates simulating a resuspension to the water column, where distilled water was added to the sediment respecting a proportion of 1:4 (mass: volume, sediment: water) (USEPA, 1998). A total of $100 \mathrm{~mL}$ of elutriate was prepared for each sample. Then, the samples were shacked manually for one minute and settled at room temperature $\left(\sim 22^{\circ} \mathrm{C}\right)$. Twenty-four hours later, the aqueous supernatant (elutriate) was collected without resuspending the sediment (Magdaleno et al., 2008; Messias, 2008). Distilled water was used as negative control and followed the same steps as elutriate preparation but without sediment. Therefore, five treatments were done and named NC, FNS, CDU, SNF, and FUN (for Negative Control, Furnas, Chapéu D'Uvas, Santa Fé, and Funil, respectively). Sediment elutriates were then used for Allium exposure and metal quantification as specified below.

\section{Metal quantification}

Cellulose acetate membrane (Whatman, $0.45 \mu \mathrm{m}$ ) was used to filter the sediment elutriates, and $\mathrm{Cu}, \mathrm{Cr}, \mathrm{Cd}, \mathrm{Pb}, \mathrm{Zn}$, and Fe were quantified by flame atomic absorption spectrometry

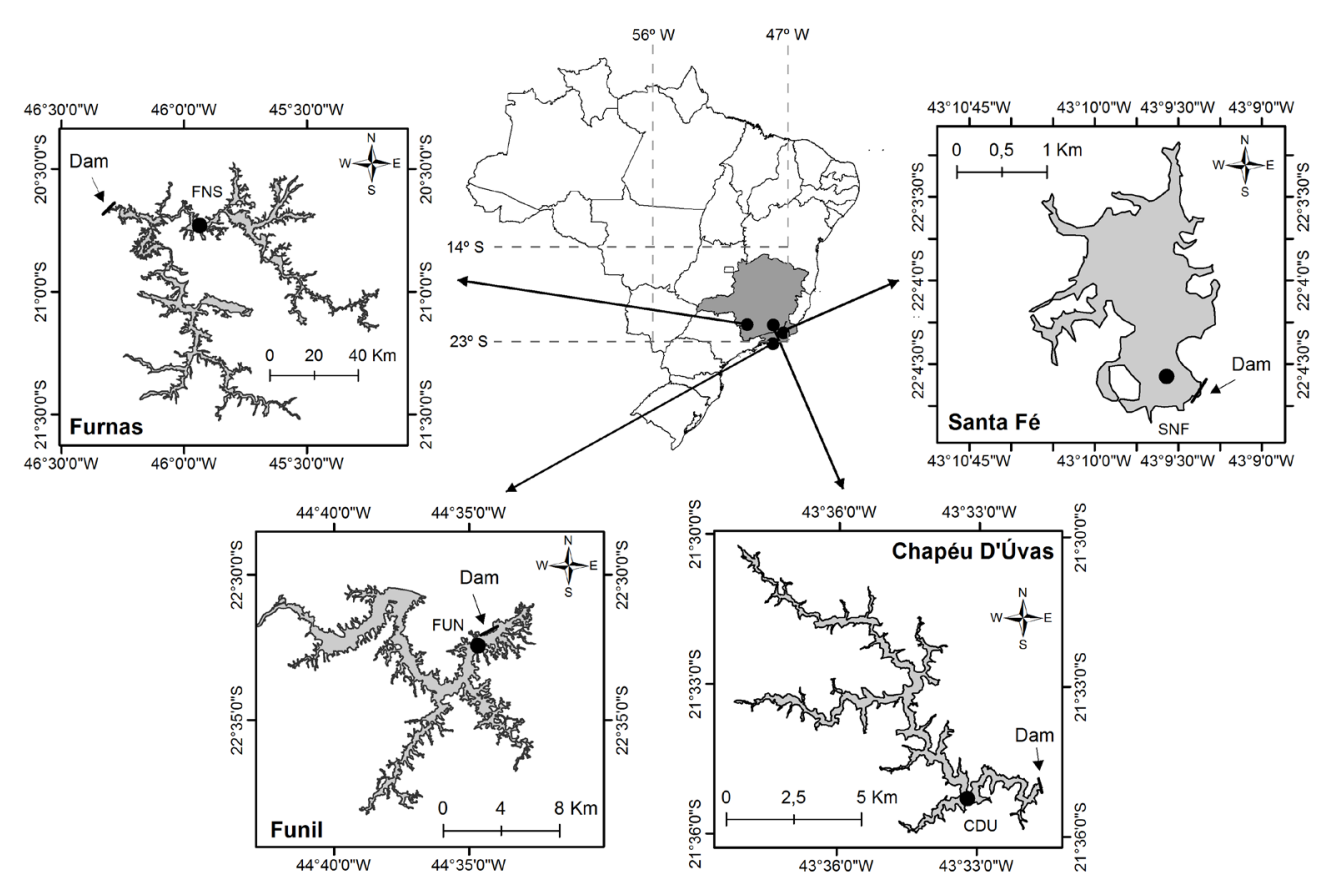

Figure 1. Study area map showing the sampled reservoirs. The gray area indicates the shape of the reservoirs as well as Minas Gerais and Rio de Janeiro states. 
(Varian, AAS240FS, Santa Clara, United States). Glassware was pretreated with a neutral detergent (Merck, 5\% for $12 \mathrm{~h}$ ) and $\mathrm{HNO}_{3}$ (Merck, $5 \%$ for $12 \mathrm{~h}$ ), and high purity deionized water was employed for analytical purposes (Milli-Q system, $18.2 \Omega \mathrm{m})$. Analytical quality control details can be seen in Quadra et al., (2019b, 2019c). The limits of detection (LOD) were $0.02 \mathrm{mg} \mathrm{L}^{-1}(\mathrm{Cu}$ and $\mathrm{Cd}), 0.2 \mathrm{mg} \mathrm{L}^{-1}(\mathrm{Cr}), 0.7 \mathrm{mg} \mathrm{L}^{-1}$ $(\mathrm{Pb}), 0.05 \mathrm{mg} \mathrm{L}^{-1}(\mathrm{Zn})$, and $0.8 \mathrm{mg} \mathrm{L}^{-1}(\mathrm{Fe})$.

\section{Allium test}

Allium test was developed using Allium cepa seeds cv. Baia Periforme (Feltrin), according to Quadra et al., (2019c). The sediment elutriates were directly exposed to the Allium test without filtering. Petri dishes with $3 \mathrm{~mL}$ of sediment elutriate solution were prepared, and six pre-germinated Allium seeds were placed in each Petri dish for $24 \mathrm{~h}$, in triplicates. The roots were then fixed in ethanol: acetic acid (3:1) solution for more $24 \mathrm{~h}$. After that, the roots were hydrolyzed for $20 \mathrm{~min}$ in $5 \mathrm{~N}$ $\mathrm{HCl}$, and six meristematic regions per replicate were smashed using the slide and coverslip. The slides were then stained with Giemsa ( $5 \%$ for $2 \mathrm{~min}$ ), and 2000 cells per slide were counted under an optical microscope (400x magnification). We assessed the mitotic index, phase indexes, and frequency of chromosomal aberrasions taking into account the number of observations divided by the total number of cells counted (Fiskesjo, 1985; Athanásio et al., 2014; Quadra et al., $2019 \mathrm{c})$. The chromosomal aberrations accessed were bridges, chromosomal breaks, c-metaphases, later segregation, chromosomal loss, and micronuclei.

\section{Data treatment}

Shapiro-Wilk and Levene tests were performed to confirm normality and variance homogeneity. Then, statistical analyses were performed by one-way analysis of variance (ANOVA) followed by Dunnett's test using $p<0.05$ as a significance threshold.

\section{RESULTS AND DISCUSSION}

The mitotic index was reduced after exposure to all elutriate samples (treatments) compared to NC, except in FNS (ANOVA followed by Dunnett, $p<0.05$; Table 1). The highest cell inhibition was found in FUN, while in FNS presented the lowest inhibition. Prophase index increased after exposure to all elutriate samples comparing to NC, except in FNS (ANOVA followed by Dunnett, $p<0.05$ ). Metaphase index increased significantly in SNF treatment, while anaphase index decreased considerably in SNF and FUN (ANOVA followed by Dunnett, $p<0.05$; Table 1 ).

The percentage of chromosomal aberrations significantly increased after exposure to all elutriate samples compared to NC, except in FNS (ANOVA followed by Dunnett, $p<0.05$, Table 2). The highest increase in the percentage of aberrations was found in SNF and FUN. Fragments were predominantly observed in SNF, while chromosomal bridges in CDU. Aneugenic alterations were mostly found in SNF and FUN. Comparing to NC, only SNF showed a significant result for c-metaphase (ANOVA followed by Dunnett, $\mathrm{p}<0.05$, Table 2). Sticky chromosomes and condensed nuclei were the most frequent changes observed (Table 2). Micronuclei frequency was also higher in all treatments comparing to $\mathrm{NC}$, except in FNS (ANOVA followed by Dunnett, $\mathrm{p}<0.05$, Figure 2). Representative images of the alterations observed during the experiment are shown in Figure 3.

Concentrations of $\mathrm{Cr}, \mathrm{Cd}$, and $\mathrm{Pb}$ were below their LOD in all sampling sites. The highest $\mathrm{Cu}$ concentration was found in FUN, $\mathrm{Zn}$ in SNF, and Fe in FNS (Table 3). The presence of metals in the reservoirs is probably associated with anthropogenic activities from the watersheds, resulting in agricultural, urban and industrial effluents discharged in the water resources (Quadra et al., 2019b). FUN is inserted in a profoundly altered watershed that receives an important contribution from domestic and industrial effluents (Neves et al., 2016). SNF reservoir is located downstream of the Juiz de Fora city, and metal contamination can be associated mainly with domestic and industrial effluents from the town (Quadra et al., 2019b). FNS contamination may also be related to industrial and domestic effluents, including the increasing tourism in the region, but agriculture is probably the major source of contaminants to the reservoir (Nogueira et al., 2009; Cavalcanti et al., 2014).

Therefore, the cytogenotoxic effects observed may be related to $\mathrm{Fe}, \mathrm{Cu}$, and $\mathrm{Zn}$ concentrations found in the reservoirs. The elutriate samples from FUN showed the highest decrease of mitotic and anaphase indexes and the highest increase of micronuclei, fragments, multipolarity, and condensed nuclei. At the same time, FUN showed the highest $\mathrm{Cu}$ concentration, which may be related to the cytogenotoxic effects observed. Palacio et al., (2005) showed that $\mathrm{Cu}$ around $0.01 \mathrm{mg} \mathrm{L}^{-1}$ was able to cause a reduction of $40 \%$ of the mean root length of $A$. серa. The concentrations found in FUN elutriates were higher than the tested by Palacio et al., (2005). Other studies also showed $\mathrm{Cu}$ genotoxic effects in plants, although the concentrations tested are higher than those found in the elutriates from the studied reservoirs. For example, Yildiz et al., (2009) found that $A$. cepa exposed to $\mathrm{Cu}$ around $0.6 \mathrm{mg} \mathrm{L}^{-1}$ showed

Table 1. Mitotic and phases indexes in meristematic cells of Allium cepa after exposure to sediment elutriate solutions from the Brazilian reservoirs.

\begin{tabular}{lccccc}
\hline Treatments & $\mathbf{M}_{\mathbf{i}}(\%)$ & Pro $_{\mathbf{i}}(\%)$ & Met $_{\mathbf{i}}(\%)$ & Ana $_{\mathbf{i}}(\%)$ & Tel $_{\mathbf{i}}(\%)$ \\
\hline NC & 7.99 & 41.37 & 30.93 & 16.4 & 11.3 \\
FNS & 7.01 & 42.78 & 30.11 & 15.67 & 11.44 \\
CDU & $5.43^{*}$ & $44.55^{*}$ & 28.9 & 17.3 & 9.3 \\
SNF & $4.63^{*}$ & $38.39^{*}$ & $37.34^{*}$ & $11.56^{*}$ & 12.71 \\
FUN & $3.85^{*}$ & $48.73^{*}$ & 27.45 & $11.34 *$ & 12.48 \\
\hline
\end{tabular}

*: Significantly different from NC (ANOVA followed by Dunnett, $\mathrm{p}<$ 0.05). $\mathrm{M}_{\mathrm{i}}$ (mitotic index); Pro (prophase index); Met (metaphase index); $\mathrm{Ana}_{\mathrm{i}}$ (anaphase index); $\mathrm{Tel}_{\mathrm{i}}$ (telophase index); $\mathrm{NC}$ (negative control); FNS (Furnas); CDU (Chapéu D’ Uvas); SNF (Santa Fé); FUN (Funil). 
Table 2. Frequency (\%) of chromosomal/cellular aberrations in meristematic cells of Allium cepa after exposure to sediment elutriate solutions from the Brazilian reservoirs.

\begin{tabular}{|c|c|c|c|c|c|c|}
\hline \multirow{2}{*}{\multicolumn{2}{|c|}{$\begin{array}{l}\text { Chromosomal/cellular alterations } \\
\text { NC }\end{array}$}} & \multicolumn{5}{|c|}{ Treatments (negative control and sediments) } \\
\hline & & $\mathrm{NC}$ & FNS & $\mathrm{CDU}$ & SNF & FUN \\
\hline \multirow{3}{*}{$\begin{array}{l}\text { Clastogenic } \\
\text { effects }\end{array}$} & Fragments & 0.86 & 0.96 & $1.85^{*}$ & 1.03 & $2.57 *$ \\
\hline & Bridges & 1.49 & 1.6 & $4.81 *$ & $4.70 *$ & $3.96 *$ \\
\hline & C-metaphase & 2.34 & 1.73 & 2.18 & $4.54 *$ & 2.74 \\
\hline \multirow{3}{*}{$\begin{array}{l}\text { Aneugenic } \\
\text { effects }\end{array}$} & Chromosome loss & 1.11 & 1.38 & 0.96 & 0.9 & 1.35 \\
\hline & Multipolarity & 1.03 & 1.03 & 1.32 & $1.51 *$ & $1.52 *$ \\
\hline & Later segregation & 1.38 & 1.38 & $1.66^{*}$ & $2.02 *$ & $1.52 *$ \\
\hline \multirow{2}{*}{ Toxic effects } & Sticky chromosomes & 4.98 & $6.92 *$ & $7.52 *$ & $12.39 *$ & $10.98 *$ \\
\hline & Condensed nuclei & 4.32 & $5.23 *$ & $8.90^{*}$ & $9.39 *$ & $10.34 *$ \\
\hline- & Total percentage of abnormalities & 6.55 & 7.45 & $10.71 *$ & $12.71 *$ & $12.59 *$ \\
\hline
\end{tabular}

*: Significantly different from NC (ANOVA followed by Dunett, $\mathrm{p}<0.05)$. NC (negative control); FNS (Furnas); CDU (Chapéu D’ Uvas); SNF (Santa Fé); FUN (Funil).

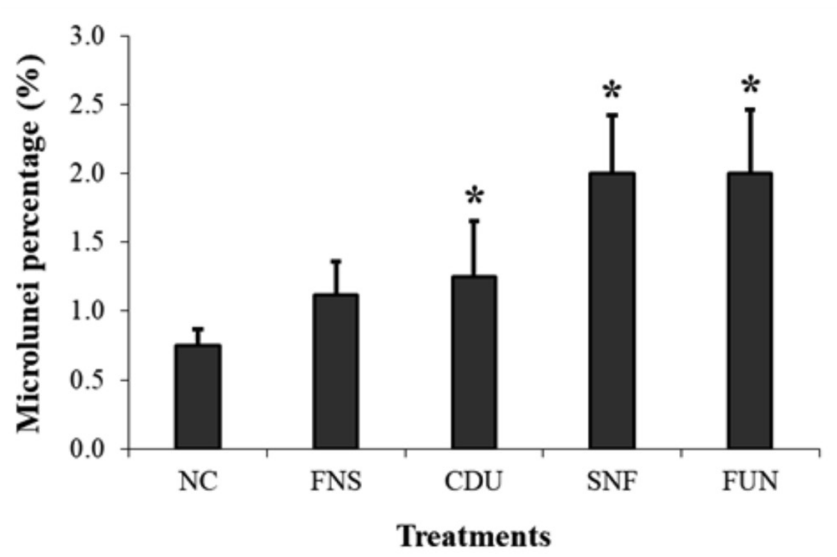

Figure 2. Micronuclei formation in meristematic cells of Allium cepa after exposure to sediment elutriate solutions from the Brazilian reservoirs. *: Significantly different from NC (ANOVA followed by Dunnett, $\mathrm{p}<0.05$ ). NC (negative control); FNS (Furnas); CDU (Chapéu D' Uvas); SNF (Santa Fé); FUN (Funil).

Table 3. Trace metal concentrations of sediment elutriate solutions from the Brazilian reservoirs used in Allium cepa exposure experiments.

\begin{tabular}{lccc}
\hline Treatments & $\mathrm{Cu}\left(\mathrm{mg} \mathrm{L}^{-1}\right)$ & $\mathrm{Zn}\left(\mathrm{mg} \mathrm{L}^{-1}\right)$ & $\mathrm{Fe}\left(\mathrm{mg} \mathrm{L}^{-1}\right)$ \\
\hline NC & $<\mathrm{LOD}$ & 0.3 & 0.4 \\
FNS & $<\mathrm{LOD}$ & 0.3 & 75.5 \\
CDU & 0.03 & 0.6 & 15.1 \\
SNF & $<\mathrm{LOD}$ & 2.4 & 51.1 \\
FUN & 0.04 & 0.7 & 58.7 \\
\hline
\end{tabular}

$<$ LOD (below limit of detection); $\mathrm{Cu}$ (copper); $\mathrm{Zn}$ (zinc); $\mathrm{Fe}$ (iron); NC (negative control); FNS (Furnas); CDU (Chapéu D' Uvas); SNF (Santa Fé); FUN (Funil).

a reduction in mitotic index and increasing the frequency of chromosomal aberrations, inducing DNA damage. Moreover, Muccifora \& Bellani et al., (2013) found that Vicia sativa seeds exposed to $0.2 \mathrm{mg} \mathrm{L}^{-1}$ affected radicle cell division and elongation.

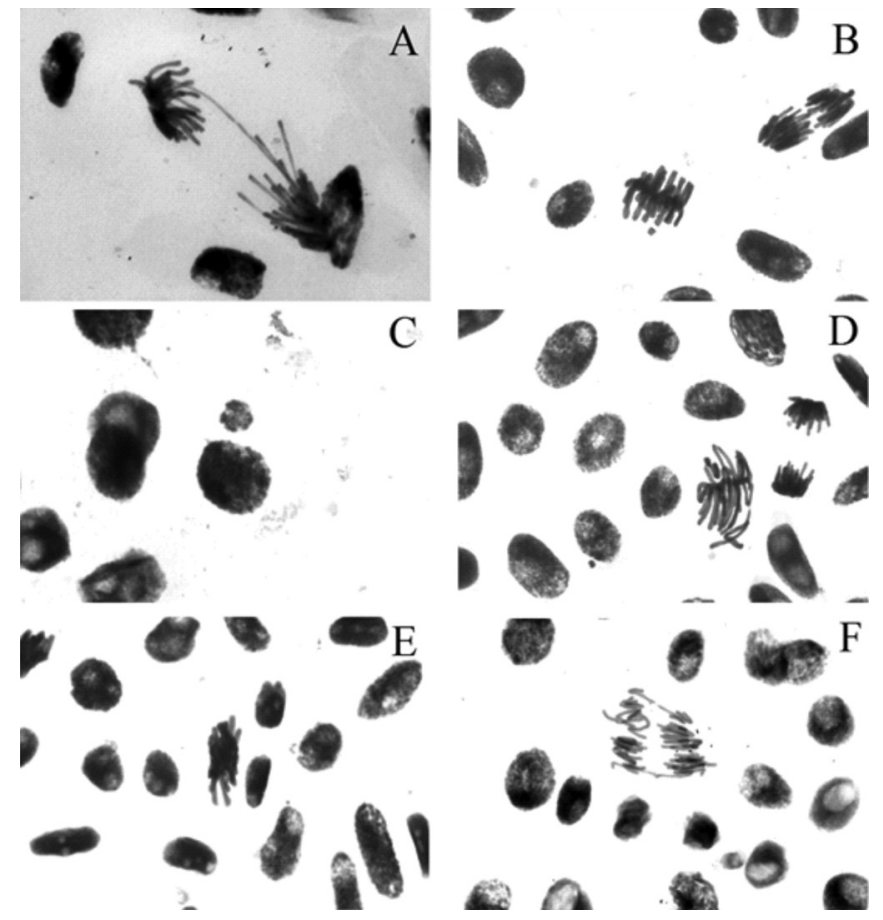

Figure 3. Examples of chromosomal aberrations observed in Allium cepa meristematic cells exposed to sediment elutriate solutions from the Brazilian reservoirs. A (bridge); B (fragment); C and D (micronucleus with different size); E (chromosome adherence); F (abnormal segregation).

Similarly, elutriate samples from SNF showed the highest $\mathrm{Zn}$ concentration and the highest decrease of prophase index and increase of micronuclei, metaphase index, c-metaphase, later segregation, sticky chromosomes, and the total percentage of chromosomal aberrations. Akbaba (2020) found that $\mathrm{Zn}$ concentrations around 20 $\mathrm{mg} \mathrm{L}^{-1}$ were able to cause genotoxic effects on the A. cepa, increasing the frequency of chromosomal aberrations. The tested $\mathrm{Zn}$ concentrations were higher than those found in the elutriates from studied reservoirs. However, the high concentration of $\mathrm{Fe}$ found in elutriate samples from 
FUN and SNF may cause synergetic effects and increase cytogenotoxicity properties. Indeed, previous studies have already documented the synergetic effects of the $\mathrm{Zn}$ and $\mathrm{Fe}$ mixture (Godet et al., 1996; Olorunfemi et al., 2013). Moreover, Paranaíba et al., (2020) performed an experiment exposing sediments to drought and comparing them to permanently flooded sediments. The authors found a significant mitotic index reduction and aneugenic alteration increase using the Allium test in the sediments exposed to drought, which also showed a higher release of metals $(\mathrm{Zn}, \mathrm{Fe}, \mathrm{Mn}$, and $\mathrm{Cd})$ to the water column. The maximum concentrations reported in the study were $0.9 \mathrm{mg}$ $\mathrm{L}^{-1}$ for $\mathrm{Zn}$ and 10.2 for $\mathrm{Fe} \mathrm{mg} \mathrm{L}^{-1}$ (Paranaíba et al., 2020). The $\mathrm{Zn}$ concentrations found in SNF elutriates and the Fe concentrations found in all elutriate samples are higher than those reported by the experimental study. Therefore, it is more likely that the elutriate mixture of metals and other contaminants, including those that were not even measured in this study, caused the detected genotoxic effects.

The results from our study show that the input of chemicals may represent a risk to aquatic ecosystems, mainly considering the potential mixture effects, which are, overall, understudied. Biological assays are key tools to understanding the mixture effects in aquatic ecosystems (Magdaleno et al., 2008; Barbério et al., 2009). The Allium test, for example, was already used to evaluate water and sediment quality in different countries (Geras'kin et al., 2011; Matsumoto et al., 2004; Barbério et al., 2009; A thanásio et al., 2014). Therefore, our findings reinforce the applicability of the Allium test to warn about genotoxic chemicals present in freshwater ecosystems.

\section{CONCLUSIONS}

Cytogenotoxicity effects were observed using the Allium test after exposure to sediment elutriate solutions from Brazilian reservoirs. The results are probably related to the $\mathrm{Cu}, \mathrm{Zn}$, and $\mathrm{Fe}$ concentrations found in the sediment elutriates, but more likely that the mixture of metals and other contaminants, including chemicals not measured in the present study, are causing the detected genotoxic effects. Therefore, the Allium test was a sensitive tool for alerting the occurrence of genotoxic contaminants in sediment elutriates simulating resuspension to the water column in aquatic ecosystems.

\section{ACKNOWLEDGMENTS}

We thank José Paranaíba for providing the study area map. This study was financed in part by the Coordenação de Aperfeiçoamento de Pessoal de Nível Superior (CAPES) Finance Code 001 -, Fundação de Amparo à Pesquisa de Minas Gerais (FAPEMIG) and Conselho Nacional de Desenvolvimento Científico e Tecnológico (CNPq). Fieldworks were funded partially by the European Research Council under the European Union's Seventh Framework Programme (FP7/2007-2013)/ ERC grant agreement n ${ }^{\circ} 336642$.

\section{REFERENCES}

AKBABA, G. B. 2020. Toxicity assessment of zinc sulfate: A commonly used compound. Toxicol. Ind. Health, 36(10), 779787. https://doi.org/10.1177/0748233720944771.

ATHANÁSIO, C.G., PRÁ, D., \& RIEGER, A. 2014. Water quality of urban streams: The Allium cepa seeds/seedlings test as a tool for surface water monitoring. Sci. World J., https://doi. org/10.1155/2014/391367.

BARBÉRIO, A., BARROS, L., VOLTOLINI, J., \& MELLO, M. 2009. Evaluation of the cytotoxic and genotoxic potential of water from the River Paraíba do Sul, in Brazil, with the Allium cepa L. test. Braz. J. Biol., 69(3):837-842. https://doi. org/10.1590/s1519-69842009000400010.

BUSCHINI, A., GIORDANI, F., PELLACANI, C., ROSSI, C., \& POLI, P. 2008. Cytotoxic and genotoxic potential of drinking water: A comparison between two different concentration methods. Water Res., 42(8-9):1999-2006. https://doi. org/10.1016/j.watres.2007.12.005.

CARDOSO, S. J., QUADRA, G.R., RESENDE, N.DAS., \& ROLAND, F. 2019. The role of sediments in the carbon and pollutant cycles in aquatic ecosystems. Acta Limnol. Bras., 31:1-13. https://doi.org/10.1590/S2179-975X8918.

CASTRO-GONZÁLEZ, M.I., \& MÉNDEZ-ARMENTA, M. 2008. Heavy metals: Implications associated to fish consumption. Environ. Toxicol. Pharmacol., 26(3):263-271. https://doi. org/10.1016/j.etap.2008.06.001.

CAVAlCANTI, P. P., RODRIGUES, L. C. A., BEIJO, L. A., BARBOSA, S., XAVIER, T. T., MAGALHAES, F. 2014. Contamination from an affluent of Furnas reservoir by trace metals. Braz. J. Biol., 74(4), 877-885. https://doi. org/10.1590/1519-6984.07013.

CHAPMAN, D. 1996. Water Quality Assessments - A Guide to Use of Biota, Sediments and Water in Environmental Monitoring. World Health Organization.

DIETERICH, A., \& GAETE, H. 2021. Assessment of the genotoxicity of sediment elutriates from an aquatic ecosystem on Allium cepa: Limache stream in central Chile. Environ. Monit. Assess., 193(5), 1-8. https://doi.org/10.1007/s10661-021-09029-7.

EGGLETON, J., \& THOMAS, K.V. 2004. A review of factors affecting the release and bioavailability of contaminants during sediment disturbance events. Environ. Int., 30:973-980. https:// doi.org/10.1016/j.envint.2004.03.001.

FISKESJO, G. 1985. The Allium test as a standard in environmental monitoring. Hereditas, 12:99-112. https://doi. org/10.1111/j.1601-5223.1985.tb00471.x.

FREITAS, L. A. D., RAMBO, C. L., FRANSCESCON, F., BARROS, A. F. P. D., LUCCA, G. D. S. D., SIEBEL, A. M., \& MAGRO, J. D. 2017. Coal extraction causes sediment toxicity in aquatic environments in Santa Catarina, Brazil. Ambi-Agua, 12, 591-604. https://doi.org/10.4136/ambi-agua.2036.

GERAS'KIN, S., OUDALOVA, A., MICHALIK, B., DIKAREVA, N., \& DIKAREV, V. 2011. Geno-toxicity assay of sediment and water samples from the Upper Silesia post-mining areas, Poland by means of Allium-test. Chemosphere, 83(June 2014). https:// doi.org/10.1016/j.chemosphere.2011.01.008.

GODET, F., BABUT, M., BURNEL, D., VEBER, A., \& VASSEUR, P. 1996. The genotoxicity of iron and chromium in electroplating effluents. Muta. Res. Genet. Toxicol., 370: 19-28. https://doi. org/10.1016/S0165-1218(96)90123-8.

HEISE, S., BABUT, M., CASADO, C., FEILER, U., FERRARI, B. J., \& MARZIALI, L. 2020. Ecotoxicological testing of sediments and dredged material: an overlooked opportunity? J. Soils Sediments, 20(12), 4218-4228. https://doi.org/10.1007/ s11368-020-02798-7. 
LEE, R.F., \& STEINERT, S. 2003. Use of the single cell gel electrophoresis/comet assay for detecting DNA damage in aquatic (marine and freshwater) animals. Muta. Res. Rev. Muta. Res., 544(1):43-64. https://doi.org/10.1016/S1383-5742(03)00017-6.

LEMOS, T., ROSA, D. P., APARECIDA, J., ROCHA, V., \& MARIA, V. 2009. Mutagenicity assessment in a river basin influenced by agricultural, urban and industrial sources. Ecotoxicol. Environ. Saf., 72:2058-2065. https://doi.org/10.1016/j. ecoenv.2009.08.006.

MAGDALENO, A., MENDELSON, A., FABRIZIO, A., IORIO, D., RENDINA, A., \& MORETTON, J. 2008. Genotoxicity of leachates from highly polluted lowland river sediments destined for disposal in landfill. Waste Manage., 28:2134-2139. https:// doi.org/10.1016/j.wasman.2007.09.027.

MASSOUDIEH, A., BOMBARDELLI, F.A., \& GINN, T.R. 2010. A biogeochemical model of contaminant fate and transport in river waters and sediments. J. Contam. Hydrol., 112(1-4):103117. https://doi.org/10.1016/j.jconhyd.2009.11.001.

MATSUMOTO, S.T., \& MARIN-MORALES, M.A. 2004. Mutagenic Potential Evaluation of the Water of a River That Receives Tannery Effluent Using the Allium cepa Test System. Cytologia, 69(4):399-408. https://doi.org/10.1508/ cytologia.69.399.

MENDONÇA, R., MÜLLER, R.A., TRANVIK, L.J., SOBEK, S., CLOW, D., VERPOORTER, C., \& RAYMOND, P. 2017. Organic carbon burial in global lakes and reservoirs. Nat. Commun., 8(1694):1-6. https://doi.org/10.1038/s41467-01701789-6.

MESSIAS, T. G. 2008. Influência da toxicidade da água e do sedimento dos rios São Joaquim e Ribeirão Claro na bacia do Corumbataí (Universidade de São Paulo).

MUCCIFORA, S. \& BELLANI, L.M. 2013. Effects of copper on germination and reserve mobilization in Vicia sativa L. seeds. Environ. Pollut., 179:68-74. https://doi.org/10.1016/j. envpol.2013.03.061.

MUDROCH, A., \& MACKNIGHT, S.D. 1994. Handbook of techniques for aquatic sediments sampling. CRC Press. https:// doi.org/10.1201/9781466571761.

NEVES, R., LIMA, D.S., BANDEIRA, C., \& RIBEIRO, D.M. 2016. Estudo da poluição pontual e difusa na bacia de contribuição do reservatório da usina hidrelétrica de Funil utilizando modelagem espacialmente distribuída em Sistema de Informação Geográfica. 139-150. https://doi.org/10.1590/ S1413-41520201600100127676.

NOGUEIRA, D. J., CASTRO, S. C., SÁ, O. R. 2009. Utilização das brânquias de Astyanax altiparanae (Garutti \& Britski, 2000) (Teleostei, Characidae) como biomarcador de poluição ambiental no reservatório UHE Furnas - MG. Rev Bras Zoociências, 11(3).

OLORUNFEMI, D.I., OFOMATA, C.R., ALIMBA, C.G., BIOLOGY, C., \& UNIT, G. 2013. Cytogenotoxicity Assessment of a University Borehole Water Supply Using The Allium cepa Test. J. Sci. Res. Dev., 14:25-34.

OMETTO, J.P., CIMBLERIS, A.C.P., MARCO, A., ROSA, L.P., ABE, D., TUNDISI, J.G., STECH, J.L., BARROS, N., \& ROLAND, F. 2013. Carbon emission as a function of energy generation in hydroelectric reservoirs in Brazilian dry tropical biome. Energy Policy, 58:109-116. https://doi.org/10.1016/j. enpol.2013.02.041.

PALACIO, S.M., ESPINOZA-QUIÑONES, F.R., MANOZZO, R., ZENATTI, D.C., SEOLATTO, A.A., KLEBER, E., ZACARKIM, C.E., ROSSI, N., \& RIZZUTTO, M.D.A. 2005. Correlation between Heavy Metal Ions (Copper, Zinc, Lead)
Concentrations and Root Length of Allium cepa L. in Polluted River Water. Braz. Arch Biol. Technol., 48(June):191-196. https://doi.org/10.1590/S1516-89132005000400024.

PARANAÍBA, J. R., QUADRA, G., JOSUÉ, I. I., ALMEIDA, R. M., MENDONÇA, R., CARDOSO, S. J., \& BARROS, N. 2020. Sediment drying-rewetting cycles enhance greenhouse gas emissions, nutrient and trace element release, and promote water cytogenotoxicity. Plos One, 15(4), e0231082. https://doi. org/10.1371/journal.pone.0231082.

QUADRA, G.R., LINO, A., SOBEK, A., MALM, O., BARROS, N., GUIDA, Y., THOMAZ, J., MENDONÇA, R., CARDOSO, S., ESTRADA, C., RUST, F., \& ROLAND, F. $2019 \mathrm{~b}$. Environmental Risk of Metal Contamination in Sediments of Tropical Reservoirs. Bull. Environ. Contam. Toxicol. https://doi. org/10.1007/s00128-019-02668-0.

QUADRA, G.R., ROLAND, F., BARROS, N., MALM, O., LINO, A.S., AZEVEDO, G.M., THOMAZ, J.R., ANDRADE-VIEIRA, L.F.,PRAÇA-FONTES, M.M., ALMEIDA, R.M., MENDONÇA, R.F., CARDOSO, S.J., GUIDA, Y.S., \& CAMPOS, J.M.S. 2019c. Far-reaching cytogenotoxic effects of mine waste from the Fund a dam disaster in Brazil. Chemosphere, 215: 753-757. https://doi.org/10.1016/j.chemosphere.2018.10.104.

QUADRA, G.R., TEIXEIRA, J.R.P.V.A., BARROS, N., ROLAND, F., \& AMADO, A.M. 2019a. Water pollution: one of the main Limnology challenges in the Anthropocene. Acta Limnol. Bras., 31(e203):1-16. https://doi.org/10.1590/S2179-975X5118.

RAMBO, C. L., ZANOTELLI, P., DALEGRAVE, D., DE NEZ, D., SZCZEPANIK, J., CARAZEK, F., \& DAL MAGRO, J. 2017. Hydropower reservoirs: cytotoxic and genotoxic assessment using the Allium cepa root model. Environ. Sci. Pollu. Res., 24(9), 8759-8768. https://doi.org/10.1007/s11356-017-8509-4.

SCHWARZENBACH, P., EGLI, T., HOFSTETTER, T.B., GUNTEN, U. VON, \& WEHRLI, B. 2010. Global Water Pollution and Human Health. Annu. Rev. Environ. Resour., https://doi.org/10.1146/annurev-environ-100809-125342.

SOARES, M.C.S., MARINHO, M.M., HUSZAR, V.L.M., BRANCO, C.W.C., \& AZEVEDO, S.M.F.O. 2008. The effects of water retention time and watershed features on the limnology of two tropical reservoirs in Brazil. Lakes Reserv.: Res Manag, 13(4):257-269. https://doi.org/10.1111/j.14401770.2008.00379.x.

SUEN, J., \& EHEART, J.W. 2006. Reservoir management to balance ecosystem and human needs: Incorporating the paradigm of the ecological flow regime. Water Resour. Res., 42(October 2005):1-9. https://doi.org/10.1029/2005WR004314.

TUNDISI, J.G. 2018. Reservoirs: New challenges for ecosystem studies and environmental management. Water Secur., 4-5(September):1-7. https://doi.org/10.1016/j. wasec.2018.09.001.

USEPA. 1998. Great lakes dredged material testing and evaluation manual: appendix F. Environmental Protection Agency/US Army Corps of Engineers, Chicago.

YILDIZ, M., CIĞERCI, İ. H., KONUK, M., FIDAN, A. F., \& TERZI, H. 2009. Determination of genotoxic effects of copper sulphate and cobalt chloride in Allium cepa root cells by chromosome aberration and comet assays. Chemosphere, 75(7), 934-938. https://doi.org/10.1016/j.chemosphere.2009.01.023.

ZOUMIS, T., SCHMIDT, A., GRIGOROVA, L., \& CALMANO, W. 2001. Contaminants in sediments: remobilisation and demobilisation. Sci. Total Environ., 195-202. https://doi.org/ 10.1016/s0048-9697(00)00740-3. 